Abstracta Iranica Abstracta Iranica

Revue bibliographique pour le domaine irano-aryen

Volume 22 | 2001

Comptes rendus des publications de 1999

Farhang-e fārsī-e ‘āmiyāne. Tehrān, Nīlūfar, 2 vol., 1378/1999, XXIX-1523 p.

Charles-Henri de Fouchécour

\title{
OpenEdition
}

1 Journals

Édition électronique

URL : http://journals.openedition.org/abstractairanica/36965

DOI : 10.4000/abstractairanica.36965

ISSN : 1961-960X

\section{Éditeur :}

CNRS (UMR 7528 Mondes iraniens et indiens), Éditions de l'IFRI

\section{Édition imprimée}

Date de publication : 15 mai 2001

ISSN : 0240-8910

\section{Référence électronique}

Charles-Henri de Fouchécour, « Farhang-e fārsi-e 'āmiyāne. Tehrān, Nïlūfar, 2 vol., 1378/1999, XXIX-1523 p. », Abstracta Iranica [En ligne], Volume 22 | 2001, document 447, mis en ligne le 17 février 2010, consulté le 10 décembre 2020. URL : http://journals.openedition.org/abstractairanica/36965 ; DOI https://doi.org/10.4000/abstractairanica.36965

Ce document a été généré automatiquement le 10 décembre 2020.

Tous droits réservés 


\title{
Farhang-e fārsī-e 'āmiyāne. Tehrān, Nilūfar, 2 vol., 1378/1999, XXIX-1523 p.
}

\author{
Charles-Henri de Fouchécour
}

L'auteur, linguiste et traducteur d'œuvres littéraires françaises contemporaines, offre le fruit d'une longue quête de mots et d'expressions qui relèvent du langage populaire courant, principalement dans les œuvres littéraires persanes contemporaines. Dans ce dictionnaire persan-persan, on trouvera un vocabulaire, mais surtout, en abondance, des expressions de la vie ordinaire. Il est, par là, précieux. Chaque entrée, faite d'un mot ou d'une expression, est suivie de sa définition, puis d'un ou de plusieurs exemples l'illustrant en contexte, par citation avec référence. En particulier, on trouvera les nombreux verbes courants donnés dans leurs emplois très variés, on trouvera aussi de riches notices sur l'emploi des prépositions et des conjonctions de toutes sortes. Un système de renvois permet de ne pas se perdre dans la recherche des expressions, classées le plus souvent par le terme qui, en elles, importe le plus. Un dictionnaire qui rendra bien des services pour la lecture d'œuvres persanes contemporaines et pour la conversation courante.

\section{INDEX}

Thèmes : 11.1.0. Généralités 


\section{AUTEURS}

\section{CHARLES-HENRI DE FOUCHÉCOUR}

Sorbonne Nouvelle - Paris III 